\title{
Use of SFC in Extraction of Adaptogens from Brazilian Plants
}

\author{
Marcelle Fernanda Carulo \\ State University of Campinas, Campinas, Brazil \\ Email: energy.marcelle@gmail.com
}

Received October 10, 2012; revised November 15, 2012; accepted November 23, 2012

\begin{abstract}
Bioactive substances found in plants are very interesting because of their importance in medicine and foods. Species of Pfaffia genre is common in Brazil, the largest center of collection of this species. Statistics report that 11,000 tons of roots and other plants were exported in 2011. Due to the large market demand, a growth of $10 \%$ per year is estimated. One of the promising areas of study involves the supercritical fluid extraction of active compounds present in plants. The current goal is to reduce dependence on foreign markets. The extraction of bioactive compound known as Beta-Ecdysone has been studied. Statistics show that profits of exports coming from the raw material is almost ten times smaller than the extract itself. Considering this fact, we emphasize the importance of an alternative method of industrial extraction in Brazil using supercritical technology, which proves to be environmentally safe.
\end{abstract}

Keywords: Chromatography; Supercritical; Extraction; Plants; Adaptogens

\section{Introduction}

21 of the 33 species of Pfaffia is found in Central and South Americas. Brazil is the largest center for collecting this species, mainly Pfaffia glomerata and Pfaffia paniculata [1]. The root of the plant is used medicinally. It is sometimes called Brazilian Ginseng, although it is not botanically related to Asian or America Ginseng. Also referred to as "para todo" (for all things), Pfaffia has been used by indigenous peoples of the Amazon region for a wide variety of health purposes. Brazil exported 11,000 tons of roots and other Brazilian plants in 2011. Every year about 720 tons of roots and 190 tons of plant powder are exported from the country as the market demand increases [2]. The root is exported after the processing unit of washing, drying and grinding. Due to moisture in the plant the productivity is much less so approximately $70 \%$ of the root is lost. The pharmacies pay up to ten times more per kg of Pfaffia after receiving the root. Reports show that pharmacies use raw materials consisting of herbal compounds in the preparation of formulas for therapeutic prescriptions [3-5].

\subsection{Adaptogens}

Due to their adaptogenic and immune-enhancing properties, Pfaffia was reported to be more powerful than Asiatic Ginseng from the Panax plant family [6,7]. Researchers report that it has the ability to strengthen the immune system and reduce tumors [8-12]. Other re- searchers have found that Pfaffia acts primarily as a regulator of the endocrine, nervous, musculoskeletal and digestive systems without stimulating or inhibiting effects, thus classifying it as a true adaptogen [13-16]. Pfaffia is reported to increase energy flow in the body. It has been used as a tonic, an aphrodisiac, a calming agent, and in the treatment of ulcers for at least 300 years. The plant has already been in use for a long time by Brazilian Indians. Pfaffia paniculata is by far the most wellresearched of herbs. Dr. Takemoto was the first to study it in Japan and he found that the root contains pfaffic acid, which is capable of inhibiting certain types of cancerous cells [17-19]. They have been the object of pharmacological studies that support its use as an adaptogen [20-22]. These same Japanese researchers filed a US patent in 1998 for a proprietary extract (Beta-Ecdysone); it claimed (through various in vivo and in vitro studies) that their compound maintained health, enhanced the immune system, and had a tonic and an anti-allergenic effect [23-25]. A French company also filed a US patent on the topical use of these Beta-Ecdysone chemicals. Beta-Ecdysone extract strengthened the water barrier function of the skin, increased skin keratinocyte differentiation (which would be helpful for psoriasis), gave the skin a smoother, softer appearance and, improved hair appearance [26]. The overall results obtained reveal that Brazil is rich in several plants with adaptogen effects. There are other plants from which the active compounds can be extracted and the World Health Organization es- 
timates that about $85 \%$ of pharmaceutical products involve the use of plant extracts [27-30]. About $80 \%$ of the 4 billion people use plants for different purpose. Studies show that many existing commercial drugs are known by the names of herbal plants used by indigenous groups (Xerem district in the state of Rio de Janeiro, Brazil). Ethno-botanical information was obtained, and samples of all species to be determined and collected in the herbarium of the National Museum [31].

\subsection{Chemical Compounds}

An important ingredient in Pfaffia is the saponin nortriterpenoid. Six different pfaffic acid sugar compounds have been isolated from nortriterpenoid. Five of these six pfaffic acid derivatives inhibit cultured tumor cell melanomas and some of them have been reported to regulate blood sugar levels. Two plant hormones, sitosterol and stigmasterol, also occur naturally in Pfaffia. They have been reported to encourage estrogen production and reduce high serum cholesterol levels. Beta-Ecdysone, another plant steroid isolated from Pfaffia facilitates cellular oxygenation [32]. Nutritional analysis has found that Pfaffia contains 19 different amino acids, a large number of electrolytes and trace minerals including iron, magnesium, cobalt, silica, zinc and the vitamins A, B-1, $\mathrm{B}-2, \mathrm{E}, \mathrm{K}$, and pantothenic acid [33-40]. It is especially high in the trace element germanium which is considered an oxygenator and is used as a nutritional supplement for the immune system. An anabolic-type phytochemical called Beta-Ecdysone and three novel ecdysteroid glycosides can be found in high amounts in Pfaffia. It is such a rich source of $\beta$-ecdysone. It is the subject of a Japanese patent for the extraction methods employed to obtain it from Pfaffia paniculata (approximately $2.5 \mathrm{~g}$ of Beta-Ecdysone can be extracted from $400 \mathrm{~g}$ of root or $0.63 \%)$.

\subsection{Agriculture}

- Pfaffia is commonly found on the banks of major rivers located in the South, Paraná river, Ivaí, Paranapanema River, and areas in the states of Mato Grosso do Sul, Paraná and São Paulo.

- It is one of the genera occurring in riparian vegetation of the upper Paraná river in the region of semideciduous forests of subtropical or tropical climate, with rainfall between 1200 - $1500 \mathrm{~mm}$ per year.

- The plant grows partly or completely under water or very wet soils and grows best under full sunlight, mainly by the rivers and the edges of forests where it can receive enough light. It grows at altitudes up to $1000 \mathrm{~m}$. and occurs mainly in sandy soils rich in organic matter, but develops well in clay soils.

- The harvest months of root are May to July because in this autumn-winter period, the area is not flooded and the roots are more "mature" and heavier. The farmers burn the fields to clean the area from other plants and poisonous animals. Roots are dug with the aid of a shovel or bucket and bagged in polyethylene material.

- The root is sold in powder form by intermediaries or producers to wholesalers or exporters. Each harvester yields a maximum of 5 - 7 tons for a field of 1 ha. The average size of field is 24 hectares.

- The cultivation is organic and only the root is processed to obtain the active ingredients. In the experiments, we observed that in 12 months, the yield is 1.9 t/ha, in 24 months, 3.2 t/ha, and 36 months, 4.1 t/ha of dried and ground root.

- As for the content of the active compound, Beta-Ecdysone, no significant variations were found considering a harvest in 12 and 24 months of age, being between $0.67 \%$ and $0.71 \%$ [41,42].

\section{Materials and Methods}

The extracts were obtained of both Pfaffia paniculata and Pfaffia glomerata, which were cultivated in the experimental field belong to UNICAMP and located in Campinas, São Paulo.

\subsection{Processing of Pfaffia}

In Brazil, the harvesters have been responsible for the processing of root, see Figure 1. The processing of Pfaffia roots follows the steps of washing, drying and grinding in the best operational conditions. For commercial purposes the powder may be placed in gelatin capsule. The roots are washed and dried at a temperature of approximately $55^{\circ} \mathrm{C}$ to $60^{\circ} \mathrm{C}$, with monitoring until $10 \%$ $12 \%$ of the moisture is removed to enable the grinding of the root. Studies reveal that after each harvest, the roots are dried in a forced ventilation oven at $40^{\circ} \mathrm{C}$.

\subsection{Supercritical Fluid Extraction (SFE)}

The unit is comprised of a supercritical installation with two extractors, which operate in a semi-continuous mode and $\left(\mathrm{CO}_{2}\right)$ storage tank, solvent storage tank, co-solvent (ethanol, hexane or methanol) tank, water bath, pumps of high pressure, flash distillation tower, continuous distillation tower and compressor, and instruments required (PID control) for control of temperature and pressure, flow meter, gauges and valves). Also see Figure 1. The yield of SFE achieved a range from $0.18 \%$ to $0.22 \%$ dry basis, for both species, being under the following operating conditions of pressure of 200 bar and $30^{\circ} \mathrm{C}$ for Pfaffia glomerata and 200 bar and $50^{\circ} \mathrm{C}$ for Pfaffia paniculata. With the addition of ethanol as a co-solvent, the extraction yield of the Beta-Ecdysone increased to $0.56 \% \mathrm{db}$. 

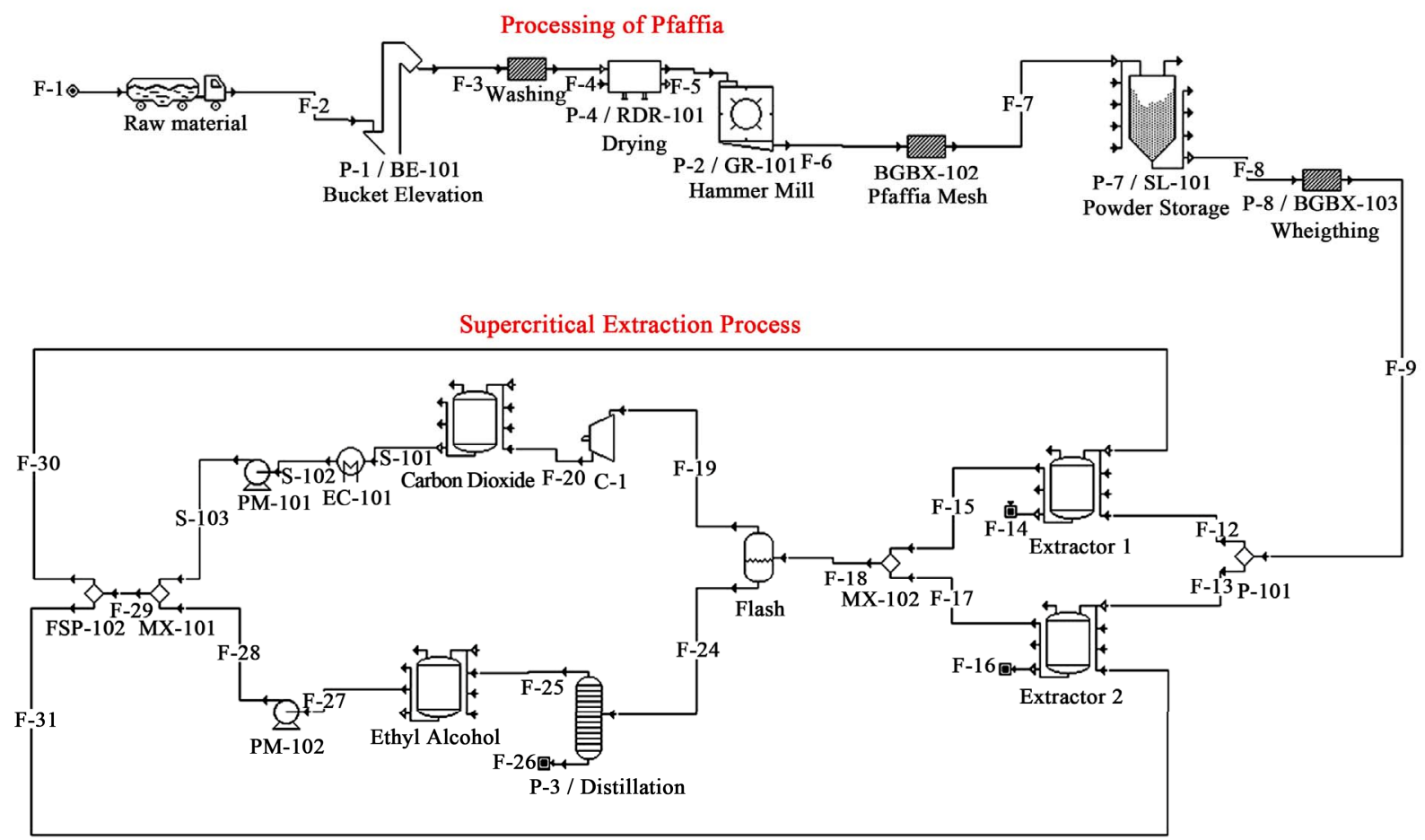

Figure 1. Flowchart of whole process.

During the process of SFE, fractions containing aproximately $4.6 \%$ of Beta-Ecdysone were obtained. This result is very important for SFE but more studies are necessary $[43,44]$.

The methods of extraction and purification of substances bioactive from roots of species of Brazilian plants may include the use of solvents or, alternatively, the use of supercritical fluids, which are classified as environmentally safe due to the absence of organic solvents in the process and the consequent generation of industrial residue [45-48]. In Brazil, the industrial extraction method used to obtain the active substance of the plants is restricted by economical viability, human resources and technology. In the foreign, there are countries, where the supercritical extraction is a common industrial method to obtain extracts from Brazilian plants.

\section{Results and Discussions}

\subsection{The Use of Supercritical Technology}

In other countries, chemical industries offer a very wide range of applications to supercritical fluids processes, especially for separation and purification of specialty chemicals using Supercritical Fluid Extraction or chromatographic processes. Industrial Development of Preparative-Scale of Supercritical Fluid Chromatography (SFC) is used to purification of extracts. In this work,
SFC must be particularly suitable due to moderately polar compounds or substances for which mass-sensitive detection is required. SFC can be considered as complementary to other chromatography and more information can be obtained from the analysis. There is no doubt that the so fast using Supercritical fluids in Brazil is opening large possibilities to substitute extracts obtained with organic solvents and to propose new high-quality products; Pfaffia can be are treated for elimination of pesticides, for example. In this work, the extract obtained was used as processed Pfaffia through appropriate purification treatment: Distillation. The extract contains BetaEcdysone and secondary metabolites such as alkaloids, terpenoids, steroids, phenols, and pigments, as well as saccharides, proteins, amino acids, nucleotides, peptides, and lipids. After isolating by chromatography, identification of compounds was carried out by comparing with other plant of data base.

\subsection{Economic Analysis}

The integrated design of the processing of roots and SFE enabled the simulation of the whole process with evaluation of mass and energy to cost analysis. The cost estimate was based on a simplified method for determineing the costs of manufacturing (COM) developed by researchers [20]. These studies concluded that despite the 
high initial investment (CI) necessary, the COM is extremely competitive with conventional extraction processes, such as drag-extraction steam and Soxhlet extraction using organic solvents.

The Brazilian government needs to encourage its own internal productive sector by tax reduction for the Brazilian made products and reducing the volume of exports of raw materials adopting more economical domestic prices. The export of raw materials accounted for \$FOB 41.234 million (11.240.906 kilograms) in 2010, generating a deficit of approximately $\$ 95$ billion, of which $\$ 25$ billion comes of imports of industrial products (chemicals and drugs). The cost of the roots was valued at $\$ 17 / \mathrm{kg}$. The cost of 60 capsules Pfaffia paniculata powder was valued at $\$ 10$, the cost of solvent $\left(\mathrm{CO}_{2}\right)$ was $\$ 2 / \mathrm{kg}$, and the cost of co-solvent (ethanol 99.9\%) was $\$ 93 / \mathrm{L}$. The transport of raw materials was also evaluated for $\$ 38$. The market offers a range of values found for the extracts from supercritical processes, which ranges between \$23 and \$6532/kg extract [44].

\section{Acknowledgements}

M. F. C. thanks to CNPq and UNICAMP by support.

\section{REFERENCES}

[1] R. B. Alves, R. A. Mendes, M. A. Mendes, R. M. D. G. Carneiro, D. B. Silva, L. D. Cardoso, A. N. Salomão and R. F. Vieira, "Brazilian Ginseng [Pfaffia Glomerata (Spreng.) Pedersen] Germplasm Conservation,” Revista Brasileira de Plantas Medicinais, Vol. 8, 2006, pp. 1-4.

[2] C. S. Freitas, C. H. Baggio, S. L. Araújo and M. C. A. Marques, "Effects of Pfaffia glomerata (Spreng) Pedersen Aqueous Extract on Healing Acetic Acid-Induced Ulcers," Brazilian Archives of Biology and Technology, Vol. 51, No. 4, 2008, pp. 355-360.

[3] G. Mazzanti, L. Braghiroli, B. Tita, P. Bolle and D. Piccinelli, "Anti-Inflammatory Action of Pfaffia paniculata (Martius) Kuntze and Pfaffia stenophylla," Pharmacological Research, Vol. 27, No. 1, 1993, pp. 91-92. doi:10.1006/phrs.1993.1080

[4] G. Mazzanti, et al., "Analgesic and Anti-Inflammatory Action of Pfaffia paniculata (Martius) Kuntze," Phytotherapy Research, Vol. 8, No. 7, 1994, pp. 413-416. doi:10.1002/ptr.2650080707

[5] F. R. Mendes and E. A. Carlini, "Brazilian Plants as Possible Adaptogens: An Ethnopharmacological Surveys of Books Edited in Brazil,” Journal of Ethnopharmacology, Vol. 109, No. 3, 2007, pp. 493-500.

doi:10.1016/j.jep.2006.08.024

[6] S. K. Ballas, "Hydration of Sickle Erythrocytes Using a Herbal Extract (Pfaffia paniculata) in vitro," British Journal of Haematology, Vol. 111, No. 1, 2000, pp. 359-362. doi:10.1046/j.1365-2141.2000.02276.x

[7] M. Bathori, "Purification and Characterization of Plant Ecdysteroids of Silene Species," TrAC Trends in Ana- lytical Chemistry, Vol. 17, No. 6, 1998, pp. 372-383. doi:10.1016/S0165-9936(98)00021-1

[8] T. C. Da Silva, A. P. Da Silva, G. Akisue, J. L. Avanzo, M. K. Nagamine, H. Fukumasu, P. Matsuzaki and M. L. Z. Dagli, et al., "Inhibitory Effects of Pfaffia paniculata (Brazilian ginseng) on Preneoplastic and Neoplastic Lesions in a Mouse Hepatocarcinogenesis Model," Cancer Letters, Vol. 226, No. 2, 2005, pp. 107-113. doi:10.1016/j.canlet.2004.12.004

[9] P. Matsuzaki, A. Gokithi, S. C. S. Oloris, S. L. Gormiak and M. L. Z. Dagli, "Effect of Pfaffia paniculata (Brazilian ginseng) on the Ehrlich Tumor in Its Ascetic Form," Life Sciences, Vol. 74, No. 5, 2003, pp. 573-579. doi:10.1016/j.lfs.2003.05.010

[10] P. Matsuzaki, M. Haraguchi, G. Akisue, S. C. Oloris, M. K. Nagamine, T. C. da Silva, M. Sakai, E. D. Fonseca, J. Palermo-Neto, S. Lima Gorniak and M. L. Dagli, "Antineoplastic Effects of Butanolic Residue of Pfaffia paniculata," Cancer Letter, Vol. 238, No. 1, 2006, pp. 85-89. doi:10.1016/j.canlet.2005.06.020

[11] T. Watanabe, "Effects of Oral Administration of Pfaffia paniculata (Brazilian ginseng) on Incidence of Spontaneous Leukemia in AKR/J Mice," Cancer Detection and Prevention Journal, Vol. 24, No. 2, 2000, pp. 173-178.

[12] Wakunaga Pharmaceutical Co., "Beta-Ecdysone from $P f a-$ ffia paniculata,” Japanese Patent No. 84 10600, 1984.

[13] R. Arletti, A. Benelli, E. Cavazzuti, G. Scarpetta, A. Bertolini, "Stimulating Property of Tumera Diffusa and Pfaffia paniculata Extracts on the Sexual Behavior of Male Rats," Psychopharmacology, Vol. 143, No. 1, 1999, pp. 15-19. doi:10.1007/s002130050913

[14] J. T. Araújo, "Brazilian Ginseng Derivative for Treatment of Sickle Cell Syntomatology,” US Patent No. 5449516, 1995.

[15] F. De-Paris, G. Neves, J. B. Salgueiro, J. Quevedo, I. Izquierdo and S. M. K. Rates, "Psychopharmacological Screening of Pfaffia glomerata Spreng (Amaranthanceae) in Rodents," Journal of Ethnopharmacology, Vol. 73, No. 1-2, 2000, pp. 261-269. doi:10.1016/S0378-8741(00)00329-9

[16] H. Gao, X.-J. Ma, X.-S. Wen and J.-Y. Si, “Advances in Study on Chemical Constituents from Plants of Genus Pfaffia and Their Bioactivities,” Zhongguo Zhongyao Zazhi, Vol. 31, No. 21, 2006, pp. 1749-1752.

[17] A. G. Neto, J. M. Costa, C. C. Belati, A. H. Vinhólis, L. S. Possebom, A. A. Da Silva Filho, W. R. Cunha, J. C. Carvalho, J. K. Bastos and M. L. e Silva, "Analgesic and Anti-Inflammatory Activity of a Crude Root Extract of Pfaffia glomerata (Spreng) Pedersen," Journal of Ethnopharmacology, Vol. 96, No. 1-2, 2005, pp. 87-91. doi:10.1016/j.jep.2004.08.035

[18] T. Takemoto, "Pfaffic Acid, a Novel Nortriterpene from Pfaffia paniculata Kuntze,” Tetrahedron Letters, Vol. 24, No. 10, 1983, pp. 1057-1060. doi:10.1016/S0040-4039(00)81603-2

[19] C. G. Teixeira, A. Piccoli, P. Costa, L. Soares and J. E. da Silva-Santos, "Involvement of the Nitric Oxide/Soluble Guanylate Cyclase Pathway in the Anti-Oedematogenic Action of Pfaffia glomerata (Spreng) Pedersen in Mice," 
Journal of Pharmacy and Pharmacol, Vol. 58, No. 5, 2006, pp. 667-675. doi:10.1211/jpp.58.5.0012

[20] I. Matsumoto, "Beta-Ecdysone from Pfaffia paniculata," Japanese Patent No. 82 118422, 1984.

[21] L. C. Marques, S. M. Galvão, E. Espínola, R. F. Dias, R. Mattei, M. G. Oliveira and E. L. De Araújo Carlini, "Psychopharmacological Assessment of Pfaffia glomerata Roots (Extract BNT-08) in Rodents," Phytotheraphy Research, Vol. 18, No. 7, 2004, pp. 566-572. doi:10.1002/ptr.1500

[22] N. Nishimoto, et al., "Three Ecdysteroid Glycosides from Pfaffia,” Phytochemistry, Vol. 27, No. 6, 1988, pp. 16651668. doi:10.1016/0031-9422(88)80422-9

[23] Rohto Pharmaceutical Co., "Pfaffic Acid and Its Derivatives,” Japanese Patent No. 84 10548, 1984.

[24] Rohto Pharmaceutical Co., "Antitumor Pfaffosides from Brazilian Carrots”, Japanese Patent No. 84 184198, 1984.

[25] T. Takemoto, "Pfaffic Acids and Its Derivatives," Japanese Patent No. SHO-WA-118872, 1982.

[26] F. Bernard, "Hair Compositions Containing a Pfaffia paniculata Extract,” FR Patent No. 1999 060991, 1999.

[27] M. Perrut, "Supercritical Fluid Applications: Industrial Developments and Economic Issues," Industrial and Engineering Chemistry Research, Vol. 39, No. 12, 2000, pp. 4531-4535. doi:10.1021/ie000211c

[28] C. S. Freitas, C. H. Baggio, J. E. Da Silva-Santos, L. Rieck, C. A. de Moraes Santos, C. C. Júnior, L. C. Ming, D. A. Garcia Cortez and M. C. Marques, "Involvement of Nitric Oxide in the Gastroprotective Effects of an Aqueous Extract of Pfaffia glomerata (Spreng) Pedersen, Amaranthaceae in Rats," Life Sciences, Vol. 74, No. 9, 2004, pp. 1167-1179. doi:10.1016/j.lfs.2003.08.003

[29] A. Meybech, "Hydrated Lipidic Lamellar Phases or Liposomes Based on Ecdysteroids,” US Patent No. 5198225, 1993.

[30] A. Meybech, F. Bonte and G. Redziniak, "Use of an Ecdysteroid for the Preparation of Cosmetic or Dermatological Compositions Intended, in Particular, for Strengthening the Water Barrier Function of the Skin or for the Preparation of a Skin Cell Culture Medium, as Well as to the Composition,” US Patent No. 5609873, 1997.

[31] L. B. Smith and R. J. Downs, “Amaranthaceae de Santa Catarina,” Flora Ilustrada Catarinense, Herbário Barbosa Rodrigues, Itajaí, 1972, pp. 35-50.

[32] A. C. M. M. Gomes, M. Nicole, J. K. Mattos, S. I. V. Pereira, P. Pereira, D. B. da Silva, R. Vieira, G. de Capdeville, A. W. Moita and R. M. D. G. Carneiro, "Concentration of $\beta$-Ecydisone (20E) in Susceptible and Resistant Accessions of Pfaffia Glomerata Infected with Meloidogyne Incognita and Histological Characterisation of Resistance," Nematology Leiden, Vol. 12, No. 5, 2010, pp. 701-709. doi:10.1163/138855409X12597616267771

[33] S. Nakai, N. Takagi, H. Miichi, S. Hayashi, N. Nishimoto, T. Takemoto and H. Kizu, "Pfaffosides, Nortriterpenoid Saponins, from Pfaffia paniculata," Phytochemistry, Vol. 23, No. 8, 1984, pp. 1703-1705. doi:10.1016/S0031-9422(00)83473-1

[34] N. Nishimoto, Y. Shiobara, M. Fujino, S.-S. Inoue, T.
Takemoto, F. de Oliveira, G. Akisue, M. K. Akisue, G. Hashimoto, O. Tanaka, R. Kasai and H. Matsuura, "Ecdysteroids from Pfaffia iresinoides and Reassignment of Some CNMR Chemical Shifts,” Phytochemistry, Vol. 26, No. 9, 1987, pp. 2505-2507. doi:10.1016/S0031-9422(00)83865-0

[35] N. Nishimoto, et al., "Pfaffosides and Nortriterpenoid Saponins from Pfaffia paniculata," Phytochemistry, Vol. 23, No. 1, 1984, pp. 139-142. doi:10.1016/0031-9422(84)83094-0

[36] M. Oshima, et al., "Pfaffia paniculata-Induced Changes in Plasma Estradiol-17-Beta, Progesterone and Testosterone Levels," Journal of Reproduction and Development, Vol. 49, No. 2, 2003, pp. 175-180. doi:10.1262/jrd.49.175

[37] K. C. Pinello, E. de S. M. Fonseca, G. Akisue, A. P. Silva, S. C. S. Olorisa, M. Sakai, P. Matsuzaki, M. K. Nagamine, J. P. Neto and M. L. Z. Daglia, "Effects of Pfaffia paniculata (Brazilian ginseng) Extract on Macrophage Activity," Life Sciences, Vol. 78, No. 12, 2006, pp. 1287-1292. doi:10.1016/j.lfs.2005.06.040

[38] T. Shibuya, T. Ario and S. Fukuda, “Composition,” US Patent No. 6224872, 2001.

[39] Y. Shiobara, S.-S. Inoue, K. Kato, Y. Nishiguchi, Y. Oishi, N. Nishimoto, F. Oliveira, G. Akisue, M. K. Akisue and G. Hashimoto, "A Nortriterpenoid, Triterpenoids and Ecdysteroids from Pfaffia glomerata," Phytochemistry, Vol. 32, No. 6, 1993, pp. 1527-1530. doi:10.1016/0031-9422(93)85172-N

[40] F. G. De Oliveira, "Contribution to the Pharmacognostic Study of Brazilian Ginseng Pfaffia paniculata," Anais de Farmácia e Química de São Paulo, Vol. 20, No. 1-2, 1980, pp. 277-361.

[41] C. P. V. Guerrelro, M. O. M. Marques, V. L. Ferracini, S. C. N. Queiroz and L. C. Ming, "Pedersen under Organic Fertilization in 6 Growth Periods [Produção de $\beta$-Ecdysone em Pfaffia Glomerata (Spreng) Pedersen em Função da Adubação Orgânica em 6 épocas de Crescimento]," Revista Brasileira de Plantas Medicinais, Vol. 11, No. 4, 2009, pp. 392-398.

[42] S. C. Heredia Vieira, S. Sólon, M. C. Vieira and N. A. Heredia Zárate, "Levantamento de Fitoterápicos Manipulados em Farmácias Magistrais de Dourados-MS,” Brazilian Journal of Pharmacognosy, Vol. 20, No. 1, 2010, pp. 28-34.

[43] J. R. V. Flora, A. S. McAnally and D. Petrides, "Treatment Plant Instructional Modules Based on SuperPro ${ }^{\circledR}$ V. 2.7,” Environmental Modelling and Software, Vol. 14, No. 1, 1999, pp. 69-80. doi:10.1016/S1364-8152(98)00059-0

[44] P. F. Leal, M. B. Kfouri, F. C. Alexandre, F. H. R. Fagundes, J. M. Prado, M. H. Toyama, M. Angela and A. Meireles, "Brazilian Ginseng Extraction via LPSE and SFE: Global Yields, Extraction Kinetics, Chemical Composition and Antioxidant Activity," The Joural of Supercritical Fluids, Vol. 54, No. 1, 2010, pp. 38-45. doi:10.1016/j.supflu.2010.03.007

[45] G. Brunner, "Supercritical Fluids: Technology and Application to Food Processing," Journal of Food Engineering, Vol. 67, No. 1-2, 2005, pp. 21-33. 


\section{doi:10.1016/j.jfoodeng.2004.05.060}

[46] H. J. Navarro Diaz, G. H. Carvalho, P. F. Leal, J. M. Prado and M. A. A. Meireles, "New Trends in Supercritical Fluids: Energy, Materials, Processing," The 9th Internatinal Symposium on Supercritical Fluids, Ecole des Mines d'Albi-Carmaux, Albi, 2009.

[47] I. M. Prado, C. L. C. Albuquerque, R. N. Cavalcanti and M. A. A. Meireles, "New Trends in Supercritical Fluids:
Energy, Materials, Processing,” The 9th Internatinal Symposium on Supercritical Fluids, Ecole des Mines d'AlbiCarmaux, Albi, 2009.

[48] S. A. Rouf, "Computer Simulation for Large Scale Bioprocess Design,” Biochemical Engineering Journal, Vol. 8, No. 3, 2001, pp. 229-234. doi:10.1016/S1369-703X(01)00112-7 